\title{
41.「妊産裖婦の全身モデル」の教育 訓練用シミュレーターの開発
}

日本赤十字看護大学

東京医科歯科大学

そこで、今回「妊産裖婦の全身モデル」の教育
I. 緒言

助産の実践では、対象の性と生殖を中心課題と してケアを行うことから、助産学教育においては 対象の生殖器に直接触れて診察（視診、触診、聴 診、計測診、内診など）を行って情報収集し、妊 娠 - 分婏 - 産裖の時期の判断や経過の判断、経過 の予測、健康逸脱の早期発見などを総合的に診断 する能力を育成することを目標にしている。その ため、学習者には、臨床実習を通して診断技術を はじめとする診断能力を習得していく過程が必須 である。

学習過程では、学習者が対象者に対して、確実 な診断と苦痛の少ないケアを行うために、臨床実 習に出る前に、基本的知識のもとに、学内で教育 用シミュレーションモデルを用いて十分に技術訓 練を行うことが必要である。

また、学習者が必要な技術を習得するためには、 臨床実習の場でケア経験を重ねることが必要だが、 少子化時代を迎えて、ケアの対象である妊産婦数 の减少に伴い、学習者がケア経験を重ねる学習の 機会も年々减少してきている。そのため、学内技 術演習は、臨床実習で対象にケアを行う前の技術 練習だけでなく、臨床実習で十分習得できなかっ た技術を臨床実習後に補足練習する目的としても 必要性が高くなっている。こうした教育現場の状 況から、学内演習で使用する教育訓練用シミュレ ーターが果たす役割は非常に大きい。
平澤美恵子、安藤広子、 鈴木恵子

○松岡 恵 訓練用シミュレーターの開発を行ったので、その 経過を報告するとともに、開発モデルの特徴を生 かして行った、学内演習のデモンストレーション をビデオにまとめたので報告する。

II.開発までの経緯と目的

研究者の一人平澤は、19 年前から、助産実践 の中核となる分婏介助や乳房管理技術の訓練用シ ミュレーターの必要性を感じて、人肌に近いシリ コーンを開発した高研（株）の技術者と提㩲して 「乳房マッサージモデル」「内診モデル」「分婏 介助モデル」「妊婦腹部触診モデル」「産裖子宮 モデル」など9つのモデルを開発してきた。これ らのモデルは各々 1 年から1年半の期間をかけて検 討して試作品を作り、試作品を臨床でテストして もらい、改善を重ねて製品化した。現在これらの モデルは、多くの看護教育機関や助産婦教育機関 で活用され、学内演習の目的である技術訓練の役 割を果たしている。

これまで開発したシミュレーションモデルは、 人体の各部分それぞれに製品化されたモデルであ るため、統合した活用は行えなかった。そのため、 各教育機関からは妊産裖婦の全身を観察してケア ができる「妊産裖婦の全身モデル」の教育訓練用 シミュレーターの開発が求められていた。そこで、 高研（株）の技術者と提㩲し、これまで開発した 
部分モデルを改良、統合して妊産裖婦の診断・ケ アを統合して実習できる「全身モデル」を開発す ることを目的として研究を行った。

\section{III. 開発の経過}

開発に要した期間は、平成 9 年度および平成 10年度の二年間だった。

平成 9 年度は、下記の既存品の改良点と、全身 モデルに組み込む機能を明確にし、全身モデルの 概要をまとめ、第一次示試作品を完成することを 目標に作業を進めた。具体的には下記の (1)〜 (3) の内容が検討された。

(1)既存品の問題点をあげ、改良点を具体的に検 討した。

（2）具体案に即して全身シミュレーターの基碮と なる部分（内診、分娩介助、妊婦腹部触診）の 試作品を作成した。

（3）目的とする機能と付加する機能、および実物 近似性を検討した。

(1)全身モデルの骨格を確認

(2)分婏介助モデル：胎盤の色調、血管分布、卵 膜の脱落膜 - 䋐毛膜 - 羊膜の剥離と性状、胎 帯の血管の走行と色調などの再検討

(3)内診モデル：産道の構造や感触、頚管成熟度、 外観などの改善状況の確認

(4)妊婦腹部触診モデル：胎児の形態や腹部から 触診時に触れる胎児部分の硬さや位置の再検 討

さらに、作業経過の中で、モデル制作工場にお いて、部品の製作過程、材質開発過程を見学し、 モデル制作作業者との意見交換を行った。

平成10年度は、第一次試作品の問題点を明らか にし、目標とする機能の組み込みの可能性を再検 討し、実用性、耐久性などを検討して、第二次試 作品を完成することを目標に作業を進めた。

第二次試作品とは、妊産袮婦の全身モデルシミ ユレーターで、妊婦の腹部診查、分婏開始および 分婏経過の内診（ビショップスコア）、フリース
タイルの分婏介助（臥位、半坐位、四つ這い、側 臥位、立位）、脆帯切断、胎盤の精查、会陰縫合、 産裖時の健康診査（子宫復古状態の触知、乳房の 診查）、分婏期弛緩出血の止血法の他、各時期に おける導尿の害際を、妊産裋婦の全身を土台にし て、演習目的に即した部品を交換しながら演習で きる試作品である。

第一次試作品から第二次試作品作成までの具体 的作業は、以下の内容である。

(1) 第一次試作品の段階で、妊産褯婦の全身に装 着可能な部品の確認：内診·導尿、腹部触診、 分婏介助、会陰縫合、産袮子宮、乳房管理の部 品装着が可能であることを確認。

(2) 平成 9 年度に問題点が指摘された装着部品の 大幅な改善状況の確認：

(1)分婏介助モデルは、胎盤の改良が検討課題と

して残されたが、軟産道の伸展が大幅に改善 され、頭位分婏のみならず、骨盤位の婏出術 (率出法)の訓練も可能になった。

(2)内診モデルは産道の構造や感触、顤管成熟度 の触感が改善されたが、恥骨結合、尾骨、坐 骨棘の位置の改善が残された。

(3)妊婦腹部触診モデルは、胎児部分の硬さと頭 部の位置が改善された。

（4）全身モデルの乳房部分は、乳腺房を作り、基 底部と乳房体の剥離状態の触感が改善された。

(5) 継続課題として、フリースタイル分婏介助訓 練に必要な股関節や有関節などの関節の可動性 と固定法、腹部大動脈の装着と止血法の訓練モ デルの装着の可能性が検討された。

IV. 結果と教育での活用

平成 10 年度に完成した第二次試作品では、止血 法を除いて当初組み込みを予定した要素に即した 作成が可能となった。さらに、分婏介助モデル部 品の軟産道の伸展が大幅に改善されたことから、 骨盤位分婏の介助演習が可能になった。 すなわち、本モデルを用いて行える訓練内容は 
以下の内容である。

\section{(1) 妊娠期の診断技術演習}

妊婦腹部触診モデルでは、レオポルド法による 腹部の外診、すなわち視診、触診、腹囲・子宮底 の計測、胎児心音聴診、胎児の先進部固定状態の 確認が行える。師が胎児の胎位、胎向を入れ替 えたり、先進部の固定部品の出し入れにより先進 部の移動や固定状態の診断能力を高めることがで きる。さらに、着带の練習も可能である。

(2) 分婏期の診断技術演習

内診モデルでは、ビショップスコア（子宮頚管 の開大度、展退、硬度、位置）を確認し、卵胞形 成の有無や破水の有無を確認できる。また、児頭 は、矢状縫合が判別できるように作成されている ため、矢状縫合の触知による胎児の回旋状態を確 認できる。ビショップスコアの確認は、モデル内 に装着する子宮口 $2-3 \mathrm{~cm}$ (子宮口の開大、位置、 柔軟性）、子宮口 5-6 cm（子宮口の開大、展退、 柔軟性、児頭の下降度、卵胞形成、破水の有無、 矢状縫合の触知）、子宮口 $8-9 \mathrm{~cm}$ （子宮口の開 大、展退、柔軟性、児頭の下降度、矢状縫合・小 泉門の触知による児頭の回旋状態）、子宮口全開 大（児頭の下降度、矢状縫合・小泉門の触知によ る児頭の回旋状態）まで 4 段階の部品を教師が入 れ替えることにより、診断能力を高めることがで きる。

分婏介助モデルは、教師が胎児モデルを回旋さ せながら動かすことにより、卧位、半坐位、四つ 這い、側臥位による分婏介助が行えるほか、骨盤 位分婏の介助（毫出法）も行える。さらに、胎盤 婏出、胎盤の精査の演習が行える。

臍帯と会陰は独立した部品を作成し、この部品 を使って、臍帯切断や会陰縫合の練習が行える。

\section{（3）産裖期の診断技術演習}

産裖子宮触診モデルは、子宮底の計測、子宮復 古の触診が行える。教師が、産裖 1 日目から 7 日 目の収縮良好または収縮不良の子宮部品を入れ替
えることにより、診断能力を高めることができる

乳房部分では、釈房の触診、乳頭の触診、乳房 の可動性の診査、乳頭マッサージを行うことがで きる。

なお、導尿の演習部品は、妊娠期、分婏期、産 裖期各期の演習で組み込むことが可能である。

（4）技術演習の実際（V T R 所要時間）

(1) 妊娠期

妊娠期の健康診査（2 分）

触診：レオポルド触診法、児頭の固定状 態

計測診：子宮底長、腹囲

聴診：胎児心音

着带 (1 分)

(2)分婏期

内診 (3 分)

分婏開始時の内診、分婏進行確認の内診 分婏介助 (7 分)

臥位、半坐位、四つ這い、側臥位、立位、 骨般位の介助

臍帯切断、胎盤の精査

会陰縫合

(3) 産裖期

産裖期の健康診查（1 分）

子宮の触知

乳房の触知

釈頭のケア

(4) 導尿（1 分）

V. 今後の課題

今回の試作品では、腹部大動脈の装着と止血法 の訓練機能を組み入れることができなかった。助 産婦が行う分婏に伴う異常への対応の訓練や、異 常の早期発見のための全身観察、急時の止血法 の技術訓練は助産婦学生だけでなく、卒業後の現 任教育にも必要である。そのため、これらの訓練 を行うためのシミュレーションモデルの開発を今 
後、検討していきたい。

なお、本研究は、平成 9 年度および 10 年度の文 部省科学研究費補助金 (基盤研究 B (展開)) 課題 番号09557223の助成を受けて行った。

\section{文献}

1)堤治他：内診等の学生教育教材開発とその使用 経験, 東京母性衛生学会誌, 8(1)，52-54，1992.

2)前島一淑：動物実験予技訓練用シミュレーター の開発, 平成 $2-4$ 年度文部省科学研究費 (総合研 究 A) 補助金研究報告書. 